\title{
Effect of Calcium and Boron Foliar Spray on Fruit Quality and Leaf Nutritional Status of "Kelsey" Plum Trees
}

\author{
H. Kabeel", Somia A. Fawaz ${ }^{*}$, E.A. Ismail", and F.A. \\ Khalaf Alla**. \\ *Horticulture Research Institute and ${ }^{* *}$ Soil, Water and \\ Environmental Research Institute, Agricultural Research \\ Centre, Cairo, Egypt.
}

\begin{abstract}
THIS INVESTIGATION was undertaken to study the effect of foliar spray with $\mathrm{Ca}$ and $\mathrm{B}$ at different concentrations on some fruiting parameters and fruit characteristics as well as leaf nutritional status of "Kelsey" plum trees. Trees were twenty-years-old, planted at 5 meters apart and budded on Mariana rootstock grown in El-Kanater Horticulture Research Station during 2008 and 2009 seasons.

Obtained data indicated that most of $\mathrm{Ca}$ and/or B foliar spray either alone or in combinations at different concentrations resulted in a positive and significant increase in fruit set $\%$ and tree yield /feddan and yield increment \% compared with the control. Whereas decreased the percentage of fruit drop in both study seasons. Moreover, fruit physical properties (weight, volume, firmness, dimensions and fruit shape index) and chemical characters (TSS \%, acidity \% and TSS/acid ratio) were significantly improved as a result of the highest rates of both $\mathrm{Ca}$ and B foliar spray treatments either alone or in combination compared to the control. In addition, leaf nutrient content of some macroelements ( $\mathrm{N}, \mathrm{P}, \mathrm{K}, \mathrm{Ca}$ and $\mathrm{Mg}$ ) and some micro-nutrients (Fe, $\mathrm{Zn}, \mathrm{Mn}$ and $\mathrm{B}$ ) were generally increased with the different treatments during both $1^{\text {st }}$ and $2^{\text {nd }}$ seasons of study.

Undoubtedly, it could be concluded that, foliar applications of (Ca) and (B) either alone or in combinations exhibited a positive and a significant influence on fruit quality of "Kelsey" plum trees. However, the highest concentration of $\left(\mathrm{Ca}_{2} \times \mathrm{B}_{2}\right)$ treatment was the most effective in improving most fruit physical and chemical properties as well as leaf nutritional content of "Kelsey" plum trees.
\end{abstract}

The variety of Kelsey plum ( $P$. salicina lindl) has been introduced to Egypt through the ADS project during 1981 which was sponsored by the Egyptian ministry of Agriculture and University of California and USAID. Although plum trees were grown in Egypt for long time, it's area is still limited and decreased as a result of insufficient chilling requirements. In Egypt during the last 10 years, the area of plum trees decreased from 8155 fed. (1993) to 2645 fed. (2010) as a result of tree decline and unsufficient of chilling requirements* Thus, Kelsy 
plum cvs. enjoys unique characteristics that should be placed in prominent position in Egyptian plum culture since it is very late variety, the fruit has good firmness and keeps very well in cold storage, thus permitting plum marketing as late in September; also there is a demand on Kelsey plum fruit in the European market (Eissa, 2003).

In addition, it is well known that, one of the best practice to increase plum tree production is a direct application of elements. An improvement in fruit production was obtained by trees treated with $\mathrm{B}$ and $\mathrm{Ca}$ which considered an important nutrient elements that exhibited a great response on fruit production and quality of plum as well as many other deciduous fruit trees. Furthermore, both B and Ca activate plant enzymes which affect on many functions of the plant such as hormones movement, activate minerals absorption, flowering and fruiting process, pollen germination, specially its influences directionality on pollen tube growth, carbohydrates, nitrogen metabolism and water relations in plants.

In this respect, a great attention is focused on the application of both nutrient elements (B and $\mathrm{Ca}$ ). Several researches were done and revealed that spraying fruit trees with $\mathrm{B}$ and $\mathrm{Ca}$ has been used successfully to correct the nutritional status and enhance fruit parameters through increasing fruit set, reducing fruit drop which increase yield and improve fruit properties (Robbertse and Coetzev , 1991, on avocado, Robbertse et al., 1990, Hisaw, 1991 and Hansch \& Mendel, 2009 on apple trees, Gobara, 1998, Kabeel et al., 1999, Youn et al., 2000 and Moon et al., 2002 on pear trees, Mehaisen \& El-Sharkawy 2005 on guava and Kabeel et al., 2010 on plum trees.

Therefore, the recent investigation was carried out to study concurrently the effect of foliar spray of boron and calcium at different concentrations either alone or in combination and to determine the best and optimal B and/or Ca foliar sprayed concentration and consequently the most effective treatments on some fruiting parameters and fruit characteristics as well as leaf nutritional status of Kelsey plum trees.

\section{Materials and Methods}

The present investigation was carried out in two consecutive seasons of 2008/2009 on 20-years old Kelsey plum trees. Trees were planted at 5 meters apart, budded on Mariana rootstock and grown in a loamy clay soil at the experimental farm of El-Kanater Horticultural Research Station, Qalyubia Governorate in Egypt. The selected trees were healthy, fruitful and almost have the same uniform in vigour and received the same agriculture practices adopted in the region. Three levels of "Ca" combined with three concentrations of "B" as foliar spray solutions were used. However, Ca spray treatments $\left(0.0,1.0\right.$ and $2.0 \%$ as calcium nitrate $\left.\mathrm{Ca}\left(\mathrm{NO}_{3}\right)_{2} 4 \mathrm{H}_{2} \mathrm{O}\right)$ and B spray treatments $(0.0,0.3$ and 0.6 concentrations as boric acid $33.5 \% \mathrm{~B})$ were sprayed twice, the first at full bloom while the second after one month of full bloom during each season. Taking into consideration that superfilm at the rate of $0.1 \%$ was added as a surfactant agent. Moreover, control trees, were sprayed with tap water. 
Accordingly, the different investigated combination of both $\mathrm{Ca}$ and $\mathrm{B}$ foliar spray treatments in this study were as follows:

1- Foliar spray with tap water (control).

2- Foliar spray with $0.3 \%$ of B.

3- Foliar spray with $0.6 \%$ of B.

4- Foliar spray with $1.0 \%$ of $\mathrm{Ca}$.

5- Foliar spray with $2.0 \%$ of $\mathrm{Ca}$.

6- Foliar spray with $0.3 \%$ of $\mathrm{B}+1.0 \%$ of Ca.

7- Foliar spray with $0.3 \%$ of $\mathrm{B}+2.0 \%$ of $\mathrm{Ca}$.

8- Foliar spray with $0.6 \%$ of $\mathrm{B}+1.0 \%$ of $\mathrm{Ca}$.

9- Foliar spray with $0.6 \%$ of $\mathrm{B}+2.0 \%$ of $\mathrm{Ca}$.

Fruit parameters

Fruit set percentage: the total number of flowers at full bloom and the initial number of fruit set at the end of the blooming stage in all treatments were counted and recorded then, the percentage of fruit set was estimated as the following equation according to Westwood (1978). 100

Fruit set $(\%)=($ Number of fruit set / total number of flowers at full bloom $) \mathrm{x}$

Fruit drop percentage: the number of fruits remained till harvest time were counted. The fruit drop percentage was estimated as the following equation.

Fruit drop $(\%)=($ Number of dropped fruit / initial number of set fruit $) \times 100$

\section{Tree productivity}

Tree yield was recorded at the harvesting time (on the first week of August at maturity stage in each season), fruits of each tree were picked, counted and weighed in $\mathrm{kg}$ then, the average yield/tree $(\mathrm{kg})$ for each treatment and theoretical yield (ton/fed.) were estimated. Also, the yield increment \% in relation to the control for each treatment was calculated as the following equations according to Kabeel (1998).

Yield increments $(\%)=[($ yield $(\mathrm{kg})$ per treatment - yield $(\mathrm{kg})$ per control $) /$ yield $(\mathrm{kg})$ per control] $\times 100$

\section{Fruit quality}

Samples of 20 mature fruits from each treatment were collected at the harvesting time and the following fruit properties were determined:

\section{Fruit physical properties}

The average fruit weight $(\mathrm{g})$; fruit volume $\left(\mathrm{ml}^{3}\right)$; fruit firmness $\left(\mathrm{Ib} / \mathrm{inch}^{2}\right)$ was determined using Magness and Tylor pressure tester with 7/18 inch plunger, fruit dimensions (height and diameter of each fruit in $\mathrm{mm}$.) by a vernier caliper and fruit shape index (fruit height/ fruit diameter ratio). 
Fruit chemical properties $\backslash$

The average percentage of total soluble solids (TSS \%) in fruit juice was determined by using a handy refractometer, fruit juice total acidity percentage as malic acid was estimated according to A.O.A.C (1985) and Vogel (1968) and TSS/acid ratio was calculated.

\section{Leaf nutrient status}

leaf mineral composition of some macro-elements i.e., $\mathrm{N}, \mathrm{P}, \mathrm{K}, \mathrm{Ca}$ and $\mathrm{Mg}$ (\%) and some micro nutrients such as Fe, $\mathrm{Zn}, \mathrm{Mn}$ and B (ppm) were determined. The following procedures were used.

Total nitrogen content was determined by the modified micro-Kjeldahl method described by Pregl (1945), while total phosphorus content determination was carried out colormeterically according to Murphy and Reily (1962). Leaves K, $\mathrm{Ca}, \mathrm{Mg}, \mathrm{Fe}, \mathrm{Zn}, \mathrm{Mn}$ and B contents were determined by using the Atomic Absorption Spectrophotometer (3300) according to Jackson \& Ulrich (1959) and Chapman \& Pratt (1961).

\section{* Statistical analysis.}

All the obtained data during both seasons of study were statistically analyzed using the analysis of variance method according to Snedecor and Cochran (1990). Meanwhile, Duncan`s multiple range test at 0.05 level was used to verify the differences between means of treatments as reported by Duncan (1955).

\section{Fruit parameters}

\section{Results and Discussion}

Fruit set percentage

The obtained data during both 2008 and 2009 seasons (Table 1) declared that, fruit set \% of "Kelsey" plum trees responded specifically to the rates of "Ca" sprayed. The highest level of "Ca" i.e., " $\mathrm{Ca}_{2}$ " statistically exhibited the highest percentage of fruit set, followed by both $" \mathrm{Ca}_{1} "$ and $" \mathrm{Ca}_{0} "$ sprayed trees, respectively. However, the "Kelsey" plum trees sprayed with " $\mathrm{Ca}_{0}$ " level (control) statistically showed the least value of fruit set percentage. Such trend was detected during the two experimental seasons.

Regarding the response to the concentration of B foliar spray solution, is the data showed an evident that, spraying "Kelsay" plum trees with $\mathrm{B}$ at the higher concentration, $\left(\mathrm{B}_{2}, 0.6 \%\right)$ significantly increased fruit set percentage compared with those results in both $\mathrm{B}_{1}$ and $\mathrm{B}_{0}$, Meanwhile, the the (control) significantly resulted in the lowest fruit set percentage. This trend was true throughout the two experimental seasons.

With respect to the interaction effect of the different combinations between the three variables of each investigated factors, data in Table 1 obviously displayed that, the highest value of fruit set percentage was obtained from trees sprayed with $\mathrm{Ca}_{2} \times \mathrm{B}_{2}$ " treatment during the two seasons. The opposite trend was detected by those trees sprayed with tap water (control) treatment which 
statistically exhibited the least values of fruit set $\%$ during both experimental seasons. In addition, other "Ca x B" combinations came in between the abovementioned two extents with variable tendency of effectiveness.

\section{Fruit drop \%}

Data in Table 1 obviously declared that, the percentage of fruit drop was greatly affected by all foliar spray treatments with either $\mathrm{Ca}$ or $\mathrm{B}$. However, all investigated treatments decreased the percentage of fruit drop as compared to the control. Moreover, either $\left(\mathrm{Ca}_{2}\right)$ or $\left(\mathrm{B}_{2}\right)$ treatment significantly resulted in the lowest fruit drop percentage, whereas, the highest values of fruit drop \% were always concomitant to untreated trees (control, $\mathrm{Ca}_{0} \& \mathrm{~B}_{0}$ ) during 2008 \& 2009 seasons. In addition, the two other treatments i.e., $\left(\mathrm{Ca}_{0}\right.$ and $\left.\mathrm{B}_{1}\right)$ were in between the aforesaid two extents.

As for the interaction effect, data revealed that fruit drop \% responded significantly to all sprayed treatments under study as compared to the control during both study seasons. Moreover, the least significant value of fruit drop was always connected to trees sprayed with $\left(\mathrm{Ca}_{2}\right.$ and $\left.\mathrm{B}_{2}\right)$ followed by $\left(\mathrm{Ca}_{2} \times \mathrm{B}_{1}\right)$ treatments. In contrary, the control treatment $\left(\mathrm{Ca}_{0} \times \mathrm{B}_{0}\right)$ was superior and exhibited the highest values of fruit drop \%. However, other tested treatments were intermediate as compared to those of both abovementioned two extents. Such trend was true during both seasons.

Results concerning the percentage of both fruit set and fruit drop were in line with those by Kilany and Kilany (1991) on apple, Sourour et al., (1996), Kabeel et al., (1999), Moon et al. (2002) on pear trees, Mehaisen and El-Sharkawy (2005) on guava, Vojcik et al. (1998) and Kabeel et al. (2010) on plum fruit trees.

TABLE 1. Effect of different foliar spray $\mathrm{Ca}$ and $\mathrm{B}$ concentrations and their combinations on fruit set and fruit drop (\%) of "Kelsey" plum trees during 2008 and 2009 seasons.

\begin{tabular}{|c|c|c|c|c|c|c|c|c|}
\hline \multirow{2}{*}{ Treatments } & \multicolumn{3}{|c|}{ Fruit set \% } & \multirow{2}{*}{ Mean } & \multicolumn{3}{|c|}{ Fruit drop \% } & \multirow{2}{*}{ Mean } \\
\hline & $\mathrm{Ca}_{0}$ & $\mathrm{Ca}_{1}$ & $\mathrm{Ca}_{2}$ & & $\mathrm{Ca}_{0}$ & $\mathrm{Ca}_{1}$ & $\mathrm{Ca}_{2}$ & \\
\hline \multicolumn{9}{|c|}{2008 season } \\
\hline $\mathrm{B}_{0}$ & $7.10 \mathrm{~h}$ & $10.70 \mathrm{~g}$ & $12.40 \mathrm{c}$ & $10.07 \mathrm{C}$ & $62.00 \mathrm{a}$ & $25.90 \mathrm{~cd}$ & 23.40ef & $37.10 \mathrm{~A}$ \\
\hline $\mathrm{B}_{1}$ & $11.10 \mathrm{f}$ & $11.60 \mathrm{e}$ & $13.50 \mathrm{~b}$ & $12.07 \mathrm{~B}$ & $27.10 \mathrm{~b}$ & $25.30 \mathrm{~d}$ & $23.00 \mathrm{fg}$ & $25.13 \mathrm{~B}$ \\
\hline $\mathrm{B}_{2}$ & $12.00 \mathrm{~d}$ & $12.30 \mathrm{~cd}$ & $14.40 \mathrm{a}$ & $12.90 \mathrm{~A}$ & $26.80 \mathrm{bc}$ & $24.20 \mathrm{e}$ & $22.10 \mathrm{~g}$ & $24.37 \mathrm{C}$ \\
\hline Mean & $10.07 \mathrm{C}$ & $11.53 \mathrm{~B}$ & $13.43 \mathrm{~A}$ & & $38.63 \mathrm{~A}$ & $25.13 \mathrm{~B}$ & $22.83 \mathrm{C}$ & \\
\hline \multicolumn{9}{|c|}{2009 season } \\
\hline $\mathrm{B}_{0}$ & $5.20 \mathrm{f}$ & $7.50 \mathrm{e}$ & $9.90 \mathrm{c}$ & $7.23 \mathrm{C}$ & $55.00 \mathrm{a}$ & $22.70 \mathrm{~cd}$ & $21.90 \mathrm{~d}-\mathrm{f}$ & $33.20 \mathrm{~A}$ \\
\hline $\mathrm{B}_{1}$ & $7.70 \mathrm{e}$ & $8.40 \mathrm{~d}$ & $9.80 \mathrm{~b}$ & $8.63 \mathrm{~B}$ & $23.30 \mathrm{c}$ & $22.30 \mathrm{c}-\mathrm{e}$ & $21.43 \mathrm{ef}$ & $22.34 \mathrm{C}$ \\
\hline $\mathrm{B}_{2}$ & $8.60 \mathrm{~d}$ & $9.20 \mathrm{c}$ & $11.30 \mathrm{a}$ & $9.70 \mathrm{~A}$ & $27.50 \mathrm{~b}$ & $21.80 \mathrm{~d}-\mathrm{f}$ & $20.90 \mathrm{f}$ & $23.40 \mathrm{~B}$ \\
\hline Mean & $7.17 \mathrm{C}$ & $8.37 \mathrm{~B}$ & $10.03 \mathrm{~A}$ & & $35.27 \mathrm{~A}$ & $22.27 \mathrm{~B}$ & $21.41 \mathrm{C}$ & \\
\hline
\end{tabular}

$*$ and $* *$ refer to the specific effect of investigated calcium and boron concentrations, respectively. Capital letters were used for distinguishing between values in specific effect for each investigated factor. Meanwhile, small letters used for interaction effect of their combinations. Means followed by the same letter's are not significantly different at 0.05 level.

Egypt. J. Hort. Vol. 40, No.1 (2013) 
Yield measurements

Table 2 shows the yield measurements i.e. yield ( $\mathrm{kg} / \mathrm{tree}$ and ton/fed.) and it's increments \% compared to the control in response to the specific effect of Ca spraying levels. Data revealed that, spraying trees with the highest level of $\mathrm{Ca} " \mathrm{Ca}_{2} "$ significantly resulted in the greatest values of tree yield during both 2008 and 2009 seasons. Moreover, the opposite trend was detected with plum trees sprayed with " $\mathrm{Ca}_{0}$ ". Meanwhile, the " $\mathrm{Ca}_{1} "$ sprayed trees were statistically intermediated when compared to that of the two other Ca sprayed rates as their yield expressed as $\mathrm{kg} / \mathrm{tree}$, ton/fed. and yield increment $\%$ in relation to the control. Such trend was true during both seasons.

On the other hand, the abovementioned three yield measurements of trees responded specifically to the various $\mathrm{B}$ foliar sprays solutions. Whereas, $\mathrm{B}_{2}$ foliar spray treatment was statistically the superior, while the opposite trend was true with the $\mathrm{B}_{0}$ (water spray). Moreover, the foliar with $\mathrm{B}_{1}$ concentration treatment ranked statistically second as compared to either the superior treatment $" \mathrm{~B}_{2}$ " or the inferior one " $\mathrm{B}_{0}$ " during both seasons.

As for the interaction effect of the different treatment combinations, data in the same table clearly indicated that, the highest concentration " $\mathrm{B}_{2}$ " with, $\mathrm{Ca}_{2}$ in particular, exhibited the greatest and more relatively significant values than with $\mathrm{Ca}_{1}$ in all studied yield measurements. On the other hand, the control trees $\left(\mathrm{B}_{0} \mathrm{X}\right.$ $\mathrm{Ca}_{0}$ ) was statistically the inferior as exhibited the least values of the three yield parameters during both 2008 and 2009 seasons. In addition, the other combinations were in between the aforesaid discussed ones.

TABLE 2. Effect of spray Ca levels and $B$ concentrations and their combinations different foliar on yield $(\%$, ton/fed \& $\mathrm{kg} /$ tree) of "Kelsey" plum trees during 2008 and 2009 seasons.

\begin{tabular}{|c|c|c|c|c|c|c|c|c|c|c|c|c|}
\hline \multirow{2}{*}{ Treatments } & \multicolumn{3}{|c|}{ Yield \% } & \multirow{2}{*}{ Mean } & \multicolumn{3}{|c|}{ Yield (ton/fed.) } & \multirow{2}{*}{ Mean } & \multicolumn{3}{|c|}{ Yield (kg/tree) } & \multirow{2}{*}{ Mean } \\
\hline & $\mathrm{Ca}_{0}$ & $\mathrm{Ca}_{1}$ & $\mathrm{Ca}_{2}$ & & $\mathbf{C a}_{0}$ & $\mathrm{Ca}_{1}$ & $\mathrm{Ca}_{2}$ & & $\mathrm{Ca}_{0}$ & $\mathrm{Ca}_{1}$ & $\mathrm{Ca}_{2}$ & \\
\hline \multicolumn{13}{|c|}{2008 season } \\
\hline $\mathrm{B}_{0}$ & $0.00 \mathrm{f}$ & $25.91 \mathrm{de}$ & $39.92 \mathrm{c}$ & $21.95 \mathrm{C}$ & $3.740 \mathrm{f}$ & $4.715 \mathrm{e}$ & $5.242 \mathrm{~cd}$ & $4.465 \mathrm{C}$ & $22.00 \mathrm{e}$ & $27.73 d$ & $30.83 \mathrm{c}$ & $26.86 \mathrm{C}$ \\
\hline $\mathrm{B}_{1}$ & $23.80 \mathrm{e}$ & $30.80 \mathrm{~d}$ & $45.27 \mathrm{bc}$ & $33.29 \mathrm{~B}$ & $4.635 \mathrm{e}$ & $4.896 \mathrm{e}$ & $5.423 \mathrm{bc}$ & $4.985 \mathrm{~B}$ & $27.27 \mathrm{~d}$ & $28.80 \mathrm{~d}$ & $32.00 \mathrm{bc}$ & $29.36 \mathrm{~B}$ \\
\hline $\mathrm{B}_{2}$ & $31.42 \mathrm{~d}$ & $49.78 \mathrm{~b}$ & $63.48 \mathrm{a}$ & 48.2 & $4.919 \mathrm{de}$ & $5.616 \mathrm{~b}$ & $6.131 \mathrm{a}$ & 5.5 & $28.93 \mathrm{~d}$ & $33.03 \mathrm{~b}$ & $36.07 \mathrm{a}$ & $\mathrm{A}$ \\
\hline Mean & $18.41 \mathrm{C}$ & $35.50 \mathrm{~B}$ & $49.56 \mathrm{~A}$ & & $4.431 \mathrm{C}$ & $5.075 \mathrm{~B}$ & $5.599 \mathrm{~A}$ & & $26.07 \mathrm{C}$ & $29.86 \mathrm{~B}$ & $32.97 \mathrm{~A}$ & \\
\hline \multicolumn{13}{|c|}{2009 season } \\
\hline $\mathrm{B}_{0}$ & $0.00 \mathrm{e}$ & $28.62 d$ & $40.42 \mathrm{c}$ & $23.02 \mathrm{C}$ & $4.420 \mathrm{e}$ & $5.684 \mathrm{~d}$ & $6.205 \mathrm{c}$ & $5.436 \mathrm{C}$ & $26.00 \mathrm{e}$ & $33.43 \mathrm{~d}$ & $36.50 \mathrm{c}$ & $31.98 \mathrm{C}$ \\
\hline $\mathrm{B}_{1}$ & $25.17 \mathrm{~d}$ & $38.87 \mathrm{c}$ & $44.26 \mathrm{c}$ & $36.10 \mathrm{~B}$ & $5.536 \mathrm{~d}$ & $6.131 \mathrm{c}$ & $6.369 \mathrm{c}$ & $6.012 \mathrm{~B}$ & $32.57 \mathrm{~d}$ & $36.07 \mathrm{c}$ & $37.47 \mathrm{c}$ & 35.37B \\
\hline $\mathrm{B}_{2}$ & $30.37 \mathrm{~d}$ & $53.84 \mathrm{~b}$ & $63.05 \mathrm{a}$ & $49.09 \mathrm{~A}$ & $5.763 \mathrm{~d}$ & $6.806 \mathrm{~b}$ & $7.214 \mathrm{a}$ & $6.594 \mathrm{~A}$ & $33.90 \mathrm{~d}$ & $40.03 \mathrm{~b}$ & $42.43 \mathrm{a}$ & $38.79 \mathrm{~A}$ \\
\hline Mean & $18.52 \mathrm{C}$ & $40.44 \mathrm{~B}$ & $49.24 \mathrm{~A}$ & & $5.240 \mathrm{C}$ & $6.207 \mathrm{~B}$ & $6.596 \mathrm{~A}$ & & $30.82 \mathrm{C}$ & $36.51 \mathrm{~B}$ & $38.80 \mathrm{~A}$ & \\
\hline
\end{tabular}

${ }^{*}$ and ${ }^{* *}$ refer to the specific effect of investigated calcium and boron concentrations, respectively. Capital letters were used for distinguishing between values in specific effect for each investigated factor. Meanwhile, small letters used for interaction effect of their combinations. Means followed by the same letter's are not significantly different at 0.05 level. 
Obtained results regarding the response of yield measurements to the studied treatments are in agreement with findings of numbers of researchers, Kilany and Kilany (1991) on apple, Robbertse and Coetzev (1991) on avocado, Sourour et al. (1996) on pear, Vojcik et al. (1998) on plum, Kabeel et al.(1998) on persimmon, Mehaisen and El-Sharkawy (2005) on guava and Kabeel et al. (2010) on plum.

\section{Fruit quality \\ Fruit physical properties \\ Fruit weight and volume}

Concerning the average fruit weight and fruit volume as influenced by the $\mathrm{Ca}$ sprayed level, data in Table 3 revealed that, the heaviest and biggest fruits were exhibited by the $\mathrm{Ca}_{2}$ sprayed trees. On the other hand, the trees sprayed with tap water and the $\mathrm{Ca}_{1}$ sprayed trees produced fruits in between in case of their average weight and volume. Such trend was detected during both 2008 and 2009 seasons.

Regarding the specific effect of B foliar spray solution, data obtained during both the $1^{\text {st }}$ and $2^{\text {nd }}$ seasons obviously revealed the positive relationship between the $\mathrm{B}$ concentrations and both fruit weight and volume. However, the heaviest and biggest fruits were significantly produced by the $\mathrm{B}_{2}$ sprayed trees. Contrarily, the $\mathrm{B}_{0}$ sprayed trees produced significantly the lightest and smallest fruits. Moreover, the average of fruit weight and volume of $B_{1}$ sprayed trees were statistically an intermediated as compared to those of both $\mathrm{B}_{2}$ and $\mathrm{B}_{0}$ sprayed trees. Such trend was true during both seasons.

Referring the interaction effect, data in the same table pointed out that, the combination between $\left(\mathrm{Ca}_{2} \times \mathrm{B}_{2}\right)$ treatment exhibited statistically the heaviest and the biggest fruits. On the contrary, the control treatment produced significantly the lightest and the smallest fruits throughout the two seasons of study. Moreover, the other combinations recorded in between values with tendency of variability in their effectiveness as compared to the abovementioned two extents. Such trend was detected during both the first and second seasons.

\section{Fruit firmness}

Data in Table 3 concerning the specific effect of either $\mathrm{Ca}$ or $\mathrm{B}$ sprayed concentrations and their interaction effect $(\mathrm{Ca} \times \mathrm{B})$ treatments on fruit firmness. It is clearly displayed that, the previously detected trend with both fruit weight and volume was found during both 2008 and 2009 seasons of study. However, fruit flesh firmness responded to the tested foliar sprayed levels. Hence, an obvious increase in fruit flesh firmness was generally exhibited with the raising in both $(\mathrm{Ca})$ and (B) sprayed rates either alone or in combinations. Whereas, the spraying of $\left(\mathrm{Ca}_{2}\right)$ and $\left(B_{2}\right)$ either alone or in combination produced fruits having firmer flesh texture than those of either $\left(\mathrm{Ca}_{1}\right)$ and/or $\left(\mathrm{B}_{1}\right)$ sprayed trees, but differences were significant as compared to the later level during both seasons. However, the control treatment $\left(\mathrm{Ca}_{0}, \mathrm{~B}_{0}\right.$ and $\left.\mathrm{Ca}_{0} \times \mathrm{B}_{0}\right)$ revealed significantly the most softened fruits as compared to those of other investigated treatments. 
TABLE 3. Effect of different foliar spray Ca levels and B concentrations and their combinations on fruit (weight, volume and firmness) of "Kelsey" plum trees during 2008 and 2009 seasons.

\begin{tabular}{|c|c|c|c|c|c|c|c|c|c|c|c|c|}
\hline \multirow{2}{*}{ Treatments } & \multicolumn{3}{|c|}{ Fruit weight (g.) } & \multirow{2}{*}{ Mean } & \multicolumn{3}{|c|}{ Fruit volume (mm) } & \multirow{2}{*}{ Mean } & \multicolumn{3}{|c|}{ Fruit firmness (Ib/inch $\left.{ }^{2}\right)$} & \multirow{2}{*}{ Mean } \\
\hline & $\mathbf{C a}_{0}$ & $\mathrm{Ca}_{1}$ & $\mathrm{Ca}_{2}$ & & $\mathbf{C a}_{0}$ & $\mathbf{C a}_{1}$ & $\mathrm{Ca}_{2}$ & & $\mathbf{C a}_{0}$ & $\mathbf{C a}_{1}$ & $\mathrm{Ca}_{2}$ & \\
\hline \multicolumn{13}{|c|}{2008 season } \\
\hline $\mathrm{B}_{0}$ & $90.0 \mathrm{~g}$ & $118.0 \mathrm{e}$ & $122.0 \mathrm{c}$ & $110.0 \mathrm{C}$ & $88.7 \mathrm{~g}$ & $113.7 \mathrm{~d}$ & $117.0 \mathrm{c}$ & $106.4 \mathrm{C}$ & $14.87 \mathrm{~g}$ & $15.53 \mathrm{f}$ & $16.80 \mathrm{c}$ & $15.73 \mathrm{C}$ \\
\hline $\mathrm{B}_{1}$ & $99.8 \mathrm{f}$ & $118.1 \mathrm{e}$ & $131.9 \mathrm{~b}$ & $116.6 \mathrm{~B}$ & $96.3 \mathrm{f}$ & $115.0 \mathrm{~cd}$ & $125.7 \mathrm{~b}$ & $112.3 \mathrm{~B}$ & $15.67 \mathrm{f}$ & $16.10 \mathrm{e}$ & $17.30 \mathrm{~b}$ & $16.36 \mathrm{~B}$ \\
\hline $\mathrm{B}_{2}$ & $117.9 \mathrm{e}$ & $119.7 \mathrm{~d}$ & $138.4 \mathrm{a}$ & $125.4 \mathrm{~A}$ & $110.0 \mathrm{e}$ & $116.3 \mathrm{c}$ & $130.3 \mathrm{a}$ & $118.9 \mathrm{~A}$ & $16.50 \mathrm{~d}$ & $16.00 \mathrm{e}$ & $17.80 \mathrm{a}$ & $16.77 \mathrm{~A}$ \\
\hline Mean & $102.6 \mathrm{C}$ & $118.6 \mathrm{~B}$ & $130.8 \mathrm{~A}$ & & $98.3 \mathrm{C}$ & $115.0 \mathrm{~B}$ & $124.3 \mathrm{~A}$ & & $15.68 \mathrm{C}$ & $15.88 \mathrm{~B}$ & $17.30 \mathrm{~A}$ & \\
\hline \multicolumn{13}{|c|}{2009 season } \\
\hline $\mathrm{B}_{0}$ & $91.50 \mathrm{~h}$ & $120.0 \mathrm{ef}$ & $126.7 \mathrm{c}$ & $112.7 \mathrm{C}$ & $90.0 \mathrm{~h}$ & $117.7 \mathrm{ef}$ & $121.7 \mathrm{c}$ & $109.9 \mathrm{C}$ & $15.27 \mathrm{f}$ & $15.40 \mathrm{f}$ & $17.30 \mathrm{c}$ & $15.99 \mathrm{C}$ \\
\hline $\mathrm{B}_{1}$ & $106.9 \mathrm{~g}$ & $121.0 \mathrm{e}$ & $136.5 \mathrm{~b}$ & $121.5 \mathrm{~B}$ & $102.7 \mathrm{~g}$ & 118.5de & $129.3 \mathrm{~b}$ & $116.8 \mathrm{~B}$ & $16.00 \mathrm{e}$ & $15.90 \mathrm{e}$ & $17.60 \mathrm{~b}$ & $16.50 \mathrm{~B}$ \\
\hline $\mathrm{B}_{2}$ & 119.0f & $123.7 \mathrm{~d}$ & $144.0 \mathrm{a}$ & $128.9 \mathrm{~A}$ & 116.0f & $119.8 \mathrm{~cd}$ & $137.3 \mathrm{a}$ & $124.4 \mathrm{~A}$ & $16.80 \mathrm{~d}$ & $16.70 \mathrm{~d}$ & $18.13 \mathrm{a}$ & $17.21 \mathrm{~A}$ \\
\hline Mean & $105.8 \mathrm{C}$ & $121.6 \mathrm{~B}$ & $135.7 \mathrm{~A}$ & & $103.0 \mathrm{C}$ & 118.7B & $129.4 \mathrm{~A}$ & & $16.02 \mathrm{~B}$ & $16.00 \mathrm{~B}$ & $17.68 \mathrm{~A}$ & \\
\hline
\end{tabular}

${ }^{*}$ and ${ }^{* *}$ refer to the specific effect of investigated calcium and boron concentrations, respectively. Capital letters were used for distinguishing between values in specific effect for each investigated factor. Meanwhile, small letters used for interaction effect of their combinations. Means followed by the same letter's are not significantly different at 0.05 level.

Fruit dimensions (fruit height and diameter)

With respect to the specific of either $\mathrm{Ca}$ or B sprayed levels on fruit dimensions (height and diameter) Table 4 revealed that, the previously detected trend with both fruit weight and volume was also found. Hence, the greatest fruit height and the widest diameter were statistically resulted by either $\mathrm{Ca}_{2}$ or $\mathrm{B}_{2}$ sprayed trees followed by either $\left(\mathrm{Ca}_{1}\right.$ and $\left.\mathrm{Ca}_{0}\right)$ or $\left(\mathrm{B}_{1}\right.$ and $\left.\mathrm{B}_{0}\right)$ sprayed trees, respectively. Differences in fruit dimensions due to the differential investigated either $\mathrm{Ca}$ or B sprayed concentrations were significant in most cases during both seasons.

As for the interaction effect Table 4 indicated that, the specific effect of each investigated factor was directly reflected on the interaction effect of the different $\mathrm{Ca} \times \mathrm{B}$ combinations on fruit dimensions. However, trees being sprayed with the highest level $\left(\mathrm{Ca}_{2} \times \mathrm{B}_{2}\right)$ combination resulted in the greatest values of fruit dimensions. Meanwhile, the combination between the least concentration $\left(\mathrm{Ca} \times \mathrm{B}_{0}\right)$ treatment was statistically the inferior and significantly showed the least values of fruit height and diameter. The other treatments came in between the abovementioned two extents with tendency of variability in their effectiveness.

\section{Fruit shape index}

Regarding the specific effect of foliar spray with either Ca or B at different concentrations on fruit shape index of "Kelsey" plum, data in Table 4 displayed a negligible variations with all treatments during the two seasons of study except with $\left(\mathrm{Ca}_{0}\right)$ treated trees (control) in both seasons, where it revealed the least significant value. On the other hand, differences were insignificant between the three $\mathrm{Ca}$ rates and between both $\mathrm{B}_{1}$ and $\mathrm{B}_{2}$ which resulted in an equal value of fruit shape index during the first and second season of study. 
Data in the same table showed that variations in fruit shape index were due to the interaction effect of different combinations between the two studied factors. The differences in most cases were insignificant especially in the first season. Moreover, it is noticed that, both $\left(\mathrm{Ca}_{0} \times \mathrm{B}_{0}\right)$ and $\left(\mathrm{Ca}_{0} \times \mathrm{B}_{2}\right)$ in the first season, and both $\left(\mathrm{Ca}_{0} \times \mathrm{B}_{1}\right)$ and $\left(\mathrm{Ca}_{0} \times \mathrm{B}_{2}\right)$ in the second season significantly showed the lowest values of fruit shape index. Furthermore, combinations of $\left(\mathrm{Ca}_{1} \times \mathrm{B}_{1}\right),\left(\mathrm{Ca}_{1}\right.$ $\left.x B_{2}\right)$ and $\left(\mathrm{Ca}_{2} \times \mathrm{B}_{1}\right)$ in the two seasons of study resulted in the highest significant values than the other combination treatments with insignificant differences between them.

TABLE 4. Effect of different foliar spray Ca levels and B concentrations and their combinations on fruit (height, diameter and shape index) of "Kelsey" plum trees during 2008 and 2009 seasons.

\begin{tabular}{|c|c|c|c|c|c|c|c|c|c|c|c|c|}
\hline \multirow{2}{*}{ Treatments } & \multicolumn{3}{|c|}{ Fruit height (cm) } & \multirow{2}{*}{ Mean } & \multicolumn{3}{|c|}{ Fruit diameter $(\mathbf{c m})}$. & \multirow{2}{*}{ Mean } & \multicolumn{3}{|c|}{ Fruit shape index } & \multirow{2}{*}{ Mean } \\
\hline & $\mathrm{Ca}_{0}$ & $\mathbf{C a}_{1}$ & $\mathbf{C a}_{2}$ & & $\mathrm{Ca}_{0}$ & $\mathbf{C a}_{1}$ & $\mathrm{Ca}_{2}$ & & $\mathrm{Ca}_{0}$ & $\mathrm{Ca}_{1}$ & $\mathrm{Ca}_{2}$ & \\
\hline \multicolumn{13}{|c|}{2008 season } \\
\hline $\mathrm{B}_{0}$ & $5.33 \mathrm{f}$ & $5.90 \mathrm{~cd}$ & $6.37 \mathrm{a}$ & $5.87 \mathrm{~B}$ & $5.50 \mathrm{f}$ & $6.10 \mathrm{~d}$ & $6.43 \mathrm{~b}$ & $6.01 \mathrm{C}$ & $1.000 \mathrm{c}$ & $1.033 \mathrm{ab}$ & $1.050 \mathrm{a}$ & $1.028 \mathrm{~A}$ \\
\hline $\mathrm{B}_{1}$ & $5.57 \mathrm{e}$ & $5.90 \mathrm{~cd}$ & $6.20 \mathrm{ab}$ & $5.89 \mathrm{~B}$ & $5.77 \mathrm{e}$ & $6.23 \mathrm{~cd}$ & $6.40 \mathrm{~b}$ & $6.13 \mathrm{~B}$ & $1.017 \mathrm{bc}$ & $1.050 \mathrm{a}$ & $1.033 \mathrm{ab}$ & $1.033 \mathrm{~A}$ \\
\hline $\mathrm{B}_{2}$ & $5.80 \mathrm{~d}$ & $6.07 \mathrm{bc}$ & $6.43 \mathrm{a}$ & $6.10 \mathrm{~A}$ & $5.90 \mathrm{e}$ & $6.37 \mathrm{bc}$ & $6.67 \mathrm{a}$ & $6.31 \mathrm{~A}$ & $1.010 \mathrm{c}$ & $1.037 \mathrm{a}$ & $1.037 \mathrm{a}$ & $1.028 \mathrm{~A}$ \\
\hline Mean & $5.57 \mathrm{C}$ & $5.96 \mathrm{~B}$ & $6.33 \mathrm{~A}$ & & $5.72 \mathrm{C}$ & $6.23 \mathrm{~B}$ & $6.50 \mathrm{~A}$ & & $1.009 \mathrm{~B}$ & $1.040 \mathrm{~A}$ & $1.040 \mathrm{~A}$ & \\
\hline \multicolumn{13}{|c|}{2009 season } \\
\hline $\mathrm{B}_{0}$ & $5.30 \mathrm{e}$ & $4.00 \mathrm{f}$ & $5.80 \mathrm{~cd}$ & $5.03 \mathrm{C}$ & $5.47 \mathrm{de}$ & $4.37 \mathrm{f}$ & $5.97 \mathrm{c}$ & $5.247 \mathrm{C}$ & $1.030 \mathrm{~b}-\mathrm{d}$ & $1.023 \mathrm{c}-\mathrm{e}$ & $1.040 \mathrm{a}-\mathrm{c}$ & $1.031 \mathrm{~A}$ \\
\hline $\mathrm{B}_{1}$ & $5.17 \mathrm{e}$ & $5.90 \mathrm{bc}$ & $6.07 \mathrm{ab}$ & $5.71 \mathrm{~B}$ & $5.30 \mathrm{e}$ & $5.93 \mathrm{c}$ & $6.30 \mathrm{~b}$ & $5.84 \mathrm{~B}$ & $1.007 \mathrm{e}$ & $1.053 \mathrm{a}$ & $1.043 \mathrm{ab}$ & $1.034 \mathrm{~A}$ \\
\hline $\mathrm{B}_{2}$ & $5.60 \mathrm{~d}$ & $6.00 \mathrm{a}-\mathrm{c}$ & $6.20 \mathrm{a}$ & $5.93 \mathrm{~A}$ & $5.57 \mathrm{~d}$ & $6.17 \mathrm{~b}$ & $6.53 \mathrm{a}$ & $6.09 \mathrm{~A}$ & $1.020 \mathrm{de}$ & $1.057 \mathrm{a}$ & $1.033 \mathrm{~b}-\mathrm{d}$ & $1.037 \mathrm{~A}$ \\
\hline Mean & $5.36 \mathrm{~B}$ & 5.30B & $6.02 \mathrm{~A}$ & & $5.44 \mathrm{C}$ & $5.49 \mathrm{~B}$ & $6.27 \mathrm{~A}$ & & 1.010B & $1.044 \mathrm{~A}$ & $1.039 \mathrm{~A}$ & \\
\hline
\end{tabular}

${ }^{*}$ and ${ }^{* *}$ refer to the specific effect of investigated calcium and boron concentrations, respectively. Capital letters were used for distinguishing between values in specific effect for each investigated factor. Meanwhile, small letters used for interaction effect of their combinations. Means followed by the same letter's are not significantly different at 0.05 level.

\section{Fruit chemical characteristics}

Fruit juice TSS \%

Table 5 revealed that the possible relationship between fruit juice TSS \% and the $\mathrm{Ca}$ sprayed level during both the first and second seasons. Whereas, spraying trees with the highest level of $\left(\mathrm{Ca}_{2}\right)$ produced fruits with the highest percentage of TSS \% followed by the " $\mathrm{Ca}_{1} "$ sprayed trees, while the control treatment $" \mathrm{Ca}_{0}$ " ranked the last in this concern. Differences in fruit juice TSS \% due to variable level of $\mathrm{Ca}$ foliar spray were significant during both seasons of study. 
With regard to the specific effect of the $\mathrm{B}$ sprayed solution, it is quite evident that, the tap water sprayed trees $\left(\mathrm{B}_{0}\right)$ produced fruits with the lowest juice TSS \% during the two experimental seasons. The opposite trend was true with trees sprayed with B solution at $0.6 \%$ concentration $\left(\mathrm{B}_{2}\right)$, whereas the highest percentage of TSS was observed and the increase was significant, especially when compared to the $\left(\mathrm{B}_{0}\right)$ water sprayed trees during both 2008 and 2009 seasons. In addition, fruit juice TSS $\%$ of the $" \mathrm{~B}_{1}$ " sprayed trees was intermediate with the aforesaid two extents. However differences were significant as compared to the water spray $\left(\mathrm{B}_{0}\right)$, the $\mathrm{B}_{2}$ and $\mathrm{B}_{1}$ spray solution during the two seasons.

As for the interaction effect, data in the same table indicated that, trees sprayed with $\left(\mathrm{Ca}_{2} \times \mathrm{B}_{2}\right)$, during both 2008 and 2009 seasons, produced fruits with the highest percentage of TSS that surpassed statistically the analogous ones of the other $(\mathrm{Ca} \times \mathrm{B})$ combinations. Contrarily to trees sprayed with tap water $\left(\mathrm{Ca}_{0}\right.$ $\mathrm{B}_{0}$ ) which produced the poorest fruits in their juice TSS $\%$. In addition, the other combination treatments were in between the abovementioned two extents with a variable tendency of effectiveness. Such trend was true during both 2008 and 2009 seasons.

\section{Fruit juice total acidity percentage}

Table 5 shows that fruit juice total acidity percentage negatively responded to the $\mathrm{Ca}$ sprayed level. Whereas, the highest $\mathrm{Ca}$ level $\left(\mathrm{Ca}_{2}\right)$ sprayed exhibited the lowest fruit juice total acidity percentage. The specific effect of $\mathrm{Ca}$ sprayed level on fruit total acidity percentage was significant during both 2009 and 2009 seasons. Moreover, the $\left(\mathrm{Ca}_{0}\right)$ sprayed trees had significantly the highest fruit values of total acidity $\%$, followed by those sprayed with $\left(\mathrm{Ca}_{1}\right)$ and $\left(\mathrm{Ca}_{2}\right)$ levels, respecyively.

Referring the specific effect of the concentration of B sprayed solutions on fruit juice total acidity percentage, the obtained data during both seasons of study Table 5 displayed that the response was taking the same trend of TSS \% as compared to that previously detected by $\left(\mathrm{B}_{2}\right)$ during both 2008 and 2009 seasons. In addition, the other combinations treatments were in between with the abovementioned two extents with a variable tendency of effectiveness. Such trend was true during both 2008 and 2009 seasons.

\section{TSS/acid ratio}

Table 5 reveals that TSS/acid ratio followed typically the same trends previously discussed with the TSS \% regarding the response of specific effect of each investigated factor i.e., $\mathrm{Ca}$ and $\mathrm{B}$ concentrations. Such trend was true during both 2008 and 2009 seasons. However, the highest values of TSS/acid ratio were obtained with the highest level of $\mathrm{Ca}\left(\mathrm{Ca}_{2}\right)$ or the $\mathrm{B}\left(\mathrm{B}_{2}\right)$ of sprayed solutions.

Regarding the TSS/acid ratio as influenced by the interaction effect of the different $\mathrm{Ca} \times \mathrm{B}$ combinations, data in the same table revealed that the trees sprayed with the $\left(\mathrm{Ca}_{2} \times \mathrm{B}_{2}\right)$ during both seasons significantly produced fruits contained the highest values of TSS/acid ratio. Contrarily, the $\left(\begin{array}{lll}\mathrm{Ca}_{0} & \mathrm{x} & \mathrm{B}_{0}\end{array}\right)$ 
combination treatment during both 2008 and 2009 seasons resulted in the lowest values of fruit TSS/acid ratio. In addition, the other investigated ( $\mathrm{Ca} \times \mathrm{B}$ ) combination treatments were in between with the abovementioned two extents.

Generally, the data obtained concerning the response of both physical and chemical fruit characteristics to all investigated treatments are in harmony with those previously \& and Kilany (1991), Tabatabaie \& Malakouti (1998) and Kadir (2004) on apple, Youn et al. (2000) and Moon et al. (2002) on pear, Mehaisen and El-Sharkawy (2005) on guava, Vojcik et al. (1998) and Kabeel et al. (2010) on plum trees.

TABLE 5. Effect of different foliar spray Ca levels and $B$ concentrations and their combinations on TSS \%, acidity \% and TSS/acid ratio of "Kelsey" plum trees during 2008 and 2009 seasons.

\begin{tabular}{|c|c|c|c|c|c|c|c|c|c|c|c|c|}
\hline \multirow{2}{*}{ Treatments } & \multicolumn{3}{|c|}{ TSS \% } & \multirow{2}{*}{ Mean } & \multicolumn{3}{|c|}{ Acidity \% } & \multirow{2}{*}{ Mean } & \multicolumn{3}{|c|}{ TSS/acid ratio } & \multirow{2}{*}{ Mean } \\
\hline & $\mathrm{Ca}_{0}$ & $\mathrm{Ca}_{1}$ & $\mathrm{Ca}_{2}$ & & $\mathrm{Ca}_{0}$ & $\mathrm{Ca}_{1}$ & $\mathrm{Ca}_{2}$ & & $\mathrm{Ca}_{0}$ & $\mathrm{Ca}_{1}$ & $\mathrm{Ca}_{2}$ & \\
\hline \multicolumn{13}{|c|}{2008 season } \\
\hline $\mathrm{B}_{0}$ & $12.29 \mathrm{f}$ & $12.93 \mathrm{de}$ & $13.07 \mathrm{~cd}$ & $12.76 \mathrm{C}$ & $1.920 \mathrm{a}$ & $1.803 \mathrm{~b}$ & $1.700 \mathrm{~cd}$ & $1.808 \mathrm{~A}$ & $6.40 \mathrm{f}$ & $7.20 \mathrm{e}$ & $7.72 \mathrm{c}$ & $7.11 \mathrm{C}$ \\
\hline $\mathrm{B}_{1}$ & $12.88 \mathrm{e}$ & $13.00 \mathrm{de}$ & $13.23 \mathrm{~b}$ & $13.04 \mathrm{~B}$ & $1.777 \mathrm{bc}$ & $1.733 \mathrm{~b}-\mathrm{d}$ & $1.600 \mathrm{e}$ & $1.703 \mathrm{~B}$ & 7.31de & 7.53c-e & $8.29 \mathrm{~b}$ & 7.71B \\
\hline $\mathrm{B}_{2}$ & $13.17 \mathrm{bc}$ & $13.27 \mathrm{ab}$ & $13.40 \mathrm{a}$ & $13.28 \mathrm{~A}$ & $1.457 \mathrm{bc}$ & $1.667 \mathrm{de}$ & $1.500 \mathrm{f}$ & $1.641 \mathrm{C}$ & $7.54 \mathrm{c}-\mathrm{e}$ & $7.64 \mathrm{~cd}$ & $8.97 \mathrm{a}$ & $8.05 \mathrm{~A}$ \\
\hline Mean & $12.78 \mathrm{C}$ & $13.07 \mathrm{~B}$ & $13.23 \mathrm{~A}$ & & $1.818 \mathrm{~A}$ & $1.734 \mathrm{~B}$ & $1.600 \mathrm{C}$ & & $7.09 \mathrm{C}$ & $7.46 \mathrm{~B}$ & $8.33 \mathrm{~A}$ & \\
\hline \multicolumn{13}{|c|}{2009 season } \\
\hline $\mathrm{B}_{0}$ & $12.78 \mathrm{e}$ & $13.03 \mathrm{~d}$ & $13.17 \mathrm{c}$ & $12.99 \mathrm{~B}$ & $1.947 \mathrm{a}$ & $1.900 \mathrm{a}$ & $1.767 \mathrm{c}$ & $1.871 \mathrm{~A}$ & $6.57 \mathrm{f}$ & $6.87 \mathrm{ef}$ & $7.47 \mathrm{c}$ & $6.97 \mathrm{C}$ \\
\hline $\mathrm{B}_{1}$ & $12.81 \mathrm{e}$ & $13.00 \mathrm{de}$ & $13.31 \mathrm{~b}$ & $13.04 \mathrm{~B}$ & $1.900 \mathrm{a}$ & $1.800 \mathrm{bc}$ & $1.700 \mathrm{~d}$ & $1.800 \mathrm{~B}$ & $6.75 \mathrm{f}$ & $7.24 \mathrm{~cd}$ & $7.87 \mathrm{~b}$ & $7.29 \mathrm{~B}$ \\
\hline $\mathrm{B}_{2}$ & $13.00 \mathrm{~d}$ & $13.33 b$ & $13.47 \mathrm{a}$ & 13.27A & $1.833 \mathrm{~b}$ & $1.700 \mathrm{~d}$ & $1.633 \mathrm{e}$ & $1.722 \mathrm{C}$ & 7.11de & $7.86 \mathrm{~b}$ & $8.27 \mathrm{a}$ & $7.75 \mathrm{~A}$ \\
\hline Mean & $12.86 \mathrm{C}$ & $13.12 \mathrm{~B}$ & $13.31 \mathrm{~A}$ & & $1.893 \mathrm{~A}$ & $1.800 \mathrm{~B}$ & $1.700 \mathrm{C}$ & & $6.81 \mathrm{C}$ & $7.32 \mathrm{~B}$ & $7.87 \mathrm{~A}$ & \\
\hline
\end{tabular}

${ }^{*}$ and ${ }^{* *}$ refer to the specific effect of investigated calcium and boron concentrations, respectively. Capital letters were used for distinguishing between values in specific effect for each investigated factor. Meanwhile, small letters used for interaction effect of their combinations. Means followed by the same letter's are not significantly different at 0.05 level.

\section{Leaf nutrient status}

Macro nutrients ( $N, P, K, C a$ and $M g$ )

Data in Tables 6 \& 7 revealed that, leaf contents of $\mathrm{N}, \mathrm{P}, \mathrm{K}, \mathrm{Ca}$ and $\mathrm{Mg}$ were significantly increased by increasing $\mathrm{B}$ concentrations. However, the richest leaves in their macro-nutrients contents were statistically in closed relationship with the highest $\mathrm{B}$ rate treatment $\left(\mathrm{B}_{2}\right)$, followed by a descending order by those $\left(\mathrm{B}_{1}\right)$ and $\left(\mathrm{B}_{0}\right)$ treatments while the control treatment significantly resulted in the least leaves of $\mathrm{N}, \mathrm{P}, \mathrm{K}, \mathrm{Ca}$ and $\mathrm{Mg}$ contents. 
Concerning the response of abovementioned investigated macro elements to the specific effect of various Ca foliar sprayed rates, data in the same tables showed clearly that, there are a positive relationship between the rates of $\mathrm{Ca}$ foliar sprayed and leaf acro-nutrients content except with leaf $\mathrm{P}$ content. Whereas, leaf contents of $\mathrm{N}, \mathrm{K}, \mathrm{Ca}$ and $\mathrm{Mg}$ were significantly increased with raising the sprayed $\mathrm{Ca}$ rate. The highest rate of $\mathrm{Ca}$ $\left(\mathrm{Ca}_{2}\right)$ gave the greatest leaf $\mathrm{N}, \mathrm{K}, \mathrm{Ca}$ and $\mathrm{Mg}$ contents, contrarily the lowest rate $\mathrm{Ca}_{0}$ that was statistically the inferior as exhibited the poorest leaf of macro-nutrients $\mathrm{N}, \mathrm{K}$, $\mathrm{Ca}$ and $\mathrm{Mg}$ ) contents such trends were detected during the tow seasons of study.

Regarding the interaction effect of $(\mathrm{B} \times \mathrm{Ca}$ ) combinations on the leaf macroelements ( $\mathrm{N}, \mathrm{P}, \mathrm{K}$, ca and $\mathrm{Mg}$ ) content, data in Tables 6 \& 7 displayed that, trees sprayed with the $\left(\mathrm{B}_{2} \times \mathrm{Ca}_{2}\right)$ combination treatment exhibited generally the highest significant values of leaf $\mathrm{N}, \mathrm{K}, \mathrm{Ca}$ and $\mathrm{Mg}$ contents during both the first and second seasons of study. Moreover, trees sprayed with the combination treatment of $\left(\mathrm{B}_{2} \times \mathrm{Ca}_{0}\right)$ produced leaves with the highest content of $\mathrm{P}$ during both 2008 and 2009 seasons. On the other hand, the opposite trend was resulted by the combination treatment of $\mathrm{B}_{0} \mathrm{X}$ $\mathrm{Ca}_{0}$, which was statistically the inferior. In addition, other remain combination treatments $(\mathrm{B} \times \mathrm{Ca})$ were statistically in between with the abovementioned two extents with tendency of variability in their effectiveness. Such trend was true during the two experimental seasons.

TABLE 6. Effect of different foliar spray Ca levels and B concentrations and their combinations on nitrogen, phosphorus and potassium of "Kelsey" plum trees both 2008 and 2009 seasons.

\begin{tabular}{|c|c|c|c|c|c|c|c|c|c|c|c|c|}
\hline \multirow{2}{*}{ Treatments } & \multicolumn{3}{|c|}{ Nitrogen \% (N) } & \multirow{2}{*}{ Mean } & \multicolumn{3}{|c|}{ Phosphorus \% (P) } & \multirow{2}{*}{ Mean } & \multicolumn{3}{|c|}{ Potassium \% (K) } & \multirow{2}{*}{ Mean } \\
\hline & $\mathrm{Ca}_{0}$ & $\mathrm{Ca}_{1}$ & $\mathrm{Ca}_{2}$ & & $\mathrm{Ca}_{0}$ & $\mathrm{Ca}_{1}$ & $\mathrm{Ca}_{2}$ & & $\mathrm{Ca}_{0}$ & $\mathrm{Ca}_{1}$ & $\mathrm{Ca}_{2}$ & \\
\hline \multicolumn{13}{|c|}{2008 season } \\
\hline $\mathrm{B}_{0}$ & $2.13 \mathrm{f}$ & $2.23 \mathrm{e}$ & $2.37 \mathrm{~d}$ & $2.24 \mathrm{C}$ & $0.220 \mathrm{ef}$ & $0.227 \mathrm{~d}-\mathrm{f}$ & $0.213 \mathrm{f}$ & $0.220 \mathrm{~B}$ & $1.293 \mathrm{~g}$ & $1.430 \mathrm{f}$ & $1.480 \mathrm{f}$ & $1.401 \mathrm{C}$ \\
\hline $\mathrm{B}_{1}$ & $2.27 \mathrm{e}$ & $2.40 \mathrm{~d}$ & $2.53 \mathrm{c}$ & $2.40 \mathrm{~B}$ & $0.257 \mathrm{~b}$ & $0.237 \mathrm{c}-\mathrm{e}$ & $0.253 \mathrm{bc}$ & $0.249 \mathrm{~A}$ & $1.483 \mathrm{f}$ & $1.630 \mathrm{~d}$ & $1.787 \mathrm{~b}$ & $1.633 \mathrm{~B}$ \\
\hline $\mathrm{B}_{2}$ & $2.43 \mathrm{~d}$ & $2.63 \mathrm{~b}$ & $2.77 \mathrm{a}$ & $2.61 \mathrm{~A}$ & $0.277 \mathrm{a}$ & $0.243 \mathrm{~b}-\mathrm{d}$ & $0.237 \mathrm{c}-\mathrm{e}$ & $0.252 \mathrm{~A}$ & $1.567 \mathrm{e}$ & $1.710 \mathrm{c}$ & $1.880 \mathrm{a}$ & $\mathrm{A}$ \\
\hline Mean & $2.28 \mathrm{C}$ & $2.42 \mathrm{~B}$ & $2.56 \mathrm{~A}$ & & $0.251 \mathrm{~A}$ & $0.236 \mathrm{~B}$ & $0.234 \mathrm{~B}$ & & $1.448 \mathrm{C}$ & $1.590 \mathrm{~B}$ & $1.716 \mathrm{~A}$ & \\
\hline \multicolumn{13}{|c|}{2009 season } \\
\hline $\mathrm{B}_{0}$ & $2.23 \mathrm{~g}$ & $2.33 \mathrm{f}$ & $2.50 \mathrm{de}$ & $2.36 \mathrm{C}$ & $0.247 \mathrm{ef}$ & $0.250 \mathrm{ef}$ & $0.233 \mathrm{f}$ & $0.243 \mathrm{C}$ & $1.377 \mathrm{f}$ & $1.530 \mathrm{e}$ & $1.670 \mathrm{~d}$ & $1.526 \mathrm{C}$ \\
\hline $\mathrm{B}_{1}$ & $2.43 \mathrm{e}$ & $2.67 \mathrm{c}$ & $2.73 \mathrm{bc}$ & $2.61 \mathrm{~B}$ & $0.293 \mathrm{~b}$ & $0.270 \mathrm{~cd}$ & $0.253 \mathrm{de}$ & $0.272 \mathrm{~B}$ & $1.680 \mathrm{~d}$ & $1.780 \mathrm{c}$ & $1.870 \mathrm{~b}$ & $1.777 \mathrm{~B}$ \\
\hline $\mathrm{B}_{2}$ & $2.57 \mathrm{~d}$ & $2.77 \mathrm{~b}$ & $2.93 \mathrm{a}$ & $2.76 \mathrm{~A}$ & $0.323 \mathrm{a}$ & $0.283 \mathrm{bc}$ & $0.260 \mathrm{de}$ & $0.289 \mathrm{~A}$ & $1.790 \mathrm{c}$ & $1.760 \mathrm{c}$ & $1.953 \mathrm{a}$ & $1.834 \mathrm{~A}$ \\
\hline Mean & $2.41 \mathrm{C}$ & $2.59 \mathrm{~B}$ & $2.72 \mathrm{~A}$ & & $0.288 \mathrm{~A}$ & $0.268 \mathrm{~B}$ & $0.249 \mathrm{C}$ & & $1.616 \mathrm{C}$ & $1.690 \mathrm{~B}$ & $1.831 \mathrm{~A}$ & \\
\hline
\end{tabular}

${ }^{*}$ and ${ }^{* *}$ refer to the specific effect of investigated calcium and boron concentrations, respectively. Capital letters were used for distinguishing between values in specific effect for each investigated factor. Meanwhile, small letters used for interaction effect of their combinations. Means followed by the same letter's are not significantly different at 0.05 level. 
TABLE 7. Effect of different foliar spray Ca levels and B concentrations and their combinations on calcium \% and magnesium \% of "Kelsey" plum trees both 2008 and 2009 seasons.

\begin{tabular}{|c|c|c|c|c|c|c|c|c|}
\hline \multirow[b]{2}{*}{ Treatments } & \multicolumn{3}{|c|}{ Calcium \% (Ca) } & \multirow[b]{2}{*}{ Mean } & \multicolumn{3}{|c|}{ Magnesium \% (Mg) } & \multirow[b]{2}{*}{ Mean } \\
\hline & $\mathbf{C a}_{0}$ & $\mathbf{C a}_{1}$ & $\mathbf{C a}_{2}$ & & $\mathbf{C a}_{0}$ & $\mathbf{C a}_{1}$ & $\mathbf{C a}_{2}$ & \\
\hline \multicolumn{9}{|c|}{2008 season } \\
\hline $\mathrm{B}_{0}$ & $2.15 \mathrm{~h}$ & $3.09 \mathrm{e}$ & $3.51 \mathrm{~cd}$ & $2.92 \mathrm{C}$ & $34.00 \mathrm{~g}$ & $43.00 \mathrm{f}$ & $49.00 \mathrm{e}$ & $42.00 \mathrm{C}$ \\
\hline $\mathrm{B}_{1}$ & $2.39 \mathrm{~g}$ & $3.44 \mathrm{~d}$ & $3.87 \mathrm{~b}$ & $3.23 \mathrm{~B}$ & $45.00 \mathrm{f}$ & $54.00 \mathrm{~d}$ & $63.00 \mathrm{~b}$ & $54.00 \mathrm{~B}$ \\
\hline $\mathrm{B}_{2}$ & $2.65 f$ & $3.58 \mathrm{c}$ & $3.96 \mathrm{a}$ & $3.40 \mathrm{~A}$ & $51.00 \mathrm{de}$ & $59.00 \mathrm{c}$ & $74.00 \mathrm{a}$ & $61.33 \mathrm{~A}$ \\
\hline & $2.40 \mathrm{C}$ & $3.37 \mathrm{~B}$ & $3.78 \mathrm{~A}$ & 1 & $43.33 \mathrm{C}$ & $52.00 \mathrm{~B}$ & $62.00 \mathrm{~A}$ & 7 \\
\hline \multicolumn{9}{|c|}{2009 season } \\
\hline $\mathrm{B}_{0}$ & $2.37 \mathrm{~h}$ & $3.29 \mathrm{e}$ & $3.76 \mathrm{bc}$ & $3.14 \mathrm{C}$ & $38.00 \mathrm{f}$ & $48.00 \mathrm{e}$ & $55.00 \mathrm{~d}$ & $47.00 \mathrm{C}$ \\
\hline $\mathrm{B}_{1}$ & $2.52 \mathrm{~g}$ & $3.60 \mathrm{~d}$ & $3.85 \mathrm{~b}$ & $3.32 \mathrm{~B}$ & $49.00 \mathrm{e}$ & $57.00 \mathrm{~d}$ & $73.00 \mathrm{~b}$ & 59.67B \\
\hline $\mathrm{B}_{2}$ & $2.73 \mathrm{f}$ & $3.68 \mathrm{~cd}$ & $4.17 \mathrm{a}$ & $3.53 \mathrm{~A}$ & $64.00 \mathrm{c}$ & $66.00 \mathrm{c}$ & $79.00 \mathrm{a}$ & $69.67 \mathrm{~A}$ \\
\hline Mean & $2.54 \mathrm{C}$ & $3.52 \mathrm{~B}$ & $3.93 \mathrm{~A}$ & & $50.33 \mathrm{C}$ & $57.00 \mathrm{~B}$ & $69.00 \mathrm{~A}$ & \\
\hline
\end{tabular}

${ }^{*}$ and ${ }^{* *}$ refer to the specific effect of investigated calcium and boron concentrations, respectively. Capital letters were used for distinguishing between values in specific effect for each investigated factor. Meanwhile, small letters used for interaction effect of their combinations. Means followed by the same letter's are not significantly different at 0.05 level.

\section{Micro nutrients ( $F e, \mathrm{Zn}, \mathrm{Mn}$ and $\mathrm{B}$ ).}

Data represented in Tables 8 \&9 showed the leaf Fe, $\mathrm{Zn}, \mathrm{Mn}$ and B contents in response to the specific effect of $\mathrm{B}$ and $\mathrm{Ca}$ foliar sprayed treatments during the two seasons of study. It revealed that, all investigated foliar sprayed treatments either B or Ca resulted in a significant increase in leaf $\mathrm{Fe}, \mathrm{Zn}, \mathrm{Mn}$ and $\mathrm{B}$ contents as compared with the control (either $\mathrm{B}_{0}$ or $\mathrm{Ca}_{0}$ ) which recorded the poorest leaf content and the least values of the studied micro-nutrients. Moreover, either the highest concentration of $\mathrm{B}\left(\mathrm{B}_{2}\right)$ or the highest rate of $\mathrm{Ca}\left(\mathrm{Ca}_{2}\right)$ were the superior with leaf micro-nutrients content which produced the richest leaves and the highest values of $\mathrm{Fe}, \mathrm{Zn}, \mathrm{Mn}$ and $\mathrm{B}$ content in most cases during both 2008 and 2009 seasons of study.

Concerning the interaction effect of the different $\mathrm{Ca} \times \mathrm{B}$ concentrations on the leaf of some micro-nutrients contents i.e., $\mathrm{Fe}, \mathrm{Zn}, \mathrm{Mn}$ and $\mathrm{B}$ data represented in Tables 8 \& 9. It shows that, trees sprayed with the $\left(\mathrm{Ca}_{2} \times \mathrm{B}_{2}\right)$ combination generally exhibited the highest values of leaf $\mathrm{Fe}, \mathrm{Zn}, \mathrm{Mn}$ and B content during both 2008 and 2009 seasons. Moreover, the richest leaves in Fe, $\mathrm{Zn}, \mathrm{Mn}$ and B contents expressed as (ppm) were achieved by the abovementioned treatment, also the superiority of the aforesaid treatment $\left(\mathrm{Ca}_{2} \times \mathrm{B}_{2}\right)$ over the other investigated treatments was clearly observed during the two seasons of study. Contrarily, the control treatment $\left(\mathrm{Ca}_{0} \times \mathrm{B}_{0}\right)$

Egypt. J. Hort. Vol. 40, No.1 (2013) 
significantly resulted in the lowest value and the poorest leaves in $\mathrm{Fe}, \mathrm{Zn}, \mathrm{Mn}$ and $\mathrm{B}$ contents in the two experimental seasons. In addition, other "Ca x B" combinations ranked in between with the aforesaid two extents with tendency of variability in their effectiveness. Such trend was true during both the first and second seasons of study.

The obtained results regarding the response of some macro-element $(\mathrm{N}, \mathrm{P}, \mathrm{K}$, $\mathrm{Ca}$ and $\mathrm{Mg}$ ) and micro-nutrients ( $\mathrm{Fe}, \mathrm{Zn}, \mathrm{Mn}$ and $\mathrm{B}$ ) to the $\mathrm{Ca}$ and $\mathrm{B}$ foliar spray solutions either alone or in combinations are in accordance with those reported by Sourour et al. (1996), Gobara (1998), Kabeel et al. (1999) on pear fruits, Singh and Brahmachari (1999) on guava, Picchioni et al. (1995), Svagzdys (1995) and Hansch and Mendel (2009) on apple fruit trees.

TABLE 8. Effect of different foliar spray Ca levels and B concentrations and their combinations on iron (Fe) and zinc (Zn) (ppm) of "Kelsey" plum trees both 2008 and 2009 seasons.

\begin{tabular}{|c|c|c|c|c|c|c|c|c|}
\hline \multirow{2}{*}{ Treatments } & \multicolumn{3}{|c|}{ Iron (ppm) (Fe) } & \multirow{2}{*}{ Mean } & \multicolumn{3}{|c|}{ Zinc (ppm) (Zn) } & \multirow{2}{*}{ Mean } \\
\hline & $\mathrm{Ca}_{0}$ & $\mathrm{Ca}_{1}$ & $\mathbf{C a}_{2}$ & & $\mathbf{C a}_{0}$ & $\mathbf{C a}_{1}$ & $\mathbf{C a}_{2}$ & \\
\hline \multicolumn{9}{|c|}{2008 season } \\
\hline $\mathrm{B}_{0}$ & $143.7 \mathrm{~g}$ & $157.7 \mathrm{f}$ & $167.00 \mathrm{ef}$ & $156.1 \mathrm{C}$ & $21.67 \mathrm{~g}$ & $23.67 \mathrm{f}$ & $26.67 \mathrm{e}$ & $24.00 \mathrm{C}$ \\
\hline $\mathrm{B}_{1}$ & 163.0f & 187.0de & $193.7 \mathrm{~d}$ & $181.2 \mathrm{~B}$ & $26.33 \mathrm{e}$ & $27.33 \mathrm{e}$ & $33.33 \mathrm{c}$ & $29.00 \mathrm{~B}$ \\
\hline \multirow[t]{2}{*}{$\mathrm{B}_{2}$} & $177.0 \mathrm{e}$ & $207.3 \mathrm{c}$ & $230.0 \mathrm{~b}$ & $204.8 \mathrm{~A}$ & $31.00 \mathrm{~d}$ & $35.67 \mathrm{~b}$ & $40.33 a$ & $35.67 \mathrm{~A}$ \\
\hline & $161.2 \mathrm{C}$ & $184.0 \mathrm{~B}$ & $196.9 \mathrm{~A}$ & & $26.33 \mathrm{C}$ & $28.89 \mathrm{~B}$ & $33.44 \mathrm{~A}$ & \\
\hline \multicolumn{9}{|c|}{2009 season } \\
\hline $\mathrm{B}_{0}$ & $159.3 \mathrm{~g}$ & $169.0 \mathrm{fg}$ & $176.7 \mathrm{ef}$ & $168.3 \mathrm{C}$ & $23.33 \mathrm{~g}$ & $25.67 f$ & $29.33 \mathrm{e}$ & $26.11 \mathrm{C}$ \\
\hline $\mathrm{B}_{1}$ & $172.7 \mathrm{f}$ & $194.3 \mathrm{~d}$ & $206.0 \mathrm{c}$ & 191.0B & $27.33 \mathrm{ef}$ & $32.67 \mathrm{~d}$ & $39.00 \mathrm{c}$ & $33.00 \mathrm{~B}$ \\
\hline \multirow[t]{2}{*}{$\mathrm{B}_{2}$} & 186.0de & $219.7 \mathrm{~b}$ & $246.0 \mathrm{a}$ & $217.2 \mathrm{~A}$ & $34.67 \mathrm{~d}$ & $44.33 b$ & $49.67 \mathrm{a}$ & $42.89 \mathrm{~A}$ \\
\hline & $172.7 \mathrm{C}$ & 194.3B & $209.6 \mathrm{~A}$ & & $28.44 \mathrm{C}$ & $34.22 \mathrm{~B}$ & $39.33 \mathrm{~A}$ & \\
\hline
\end{tabular}

${ }^{*}$ and ${ }^{* *}$ refer to the specific effect of investigated calcium and boron concentrations, respectively. Capital letters were used for distinguishing between values in specific effect for each investigated factor. Meanwhile, small letters used for interaction effect of their combinations. Means followed by the same letter's are not significantly different at 0.05 level. 
TABLE 9. Effect of different foliar spray Ca levels and B concentrations and their combinations on manganese (Mn) and boron (B) (ppm) of "Kelsey" plum trees both 2008 and 2009 seasons.

\begin{tabular}{|c|c|c|c|c|c|c|c|c|}
\hline \multirow{2}{*}{ Treatments } & \multicolumn{3}{|c|}{ Manganese (ppm) } & \multirow{2}{*}{ Mean } & \multicolumn{3}{|c|}{ Boron (ppm) } & \multirow{2}{*}{ Mean } \\
\hline & $\mathrm{Ca}_{0}$ & $\mathrm{Ca}_{1}$ & $\mathrm{Ca}_{2}$ & & $\mathbf{C a}_{0}$ & $\mathbf{C a}_{1}$ & $\mathrm{Ca}_{2}$ & \\
\hline \multicolumn{9}{|c|}{2008 season } \\
\hline $\mathrm{B}_{0}$ & $37.67 \mathrm{f}$ & $43.00 \mathrm{e}$ & $46.33 \mathrm{~d}$ & $42.33 \mathrm{C}$ & $18.00 \mathrm{f}$ & $21.00 \mathrm{e}$ & $23.00 \mathrm{de}$ & $20.67 \mathrm{C}$ \\
\hline $\mathrm{B}_{1}$ & $47.00 \mathrm{~cd}$ & 45.33de & $51.67 \mathrm{~b}$ & $48.00 \mathrm{~B}$ & $25.00 \mathrm{~d}$ & $28.00 \mathrm{c}$ & $39.0 \mathrm{a}$ & $30.67 \mathrm{~B}$ \\
\hline \multirow[t]{2}{*}{$\mathrm{B}_{2}$} & $50.00 \mathrm{bc}$ & $50.67 \mathrm{~b}$ & $60.33 a$ & $53.67 \mathrm{~A}$ & $33.00 \mathrm{~b}$ & $34.00 \mathrm{~b}$ & $41.00 \mathrm{a}$ & $36.00 \mathrm{~A}$ \\
\hline & $44.49 \mathrm{~B}$ & $46.33 \mathrm{~B}$ & $52.78 \mathrm{~A}$ & & $25.33 \mathrm{C}$ & 27.67B & $34.33 \mathrm{~A}$ & \\
\hline \multicolumn{9}{|c|}{2009 season } \\
\hline $\mathrm{B}_{0}$ & $39.67 \mathrm{f}$ & $45.00 \mathrm{e}$ & $49.00 \mathrm{~cd}$ & $44.56 \mathrm{C}$ & $22.00 \mathrm{f}$ & $24.00 \mathrm{ef}$ & 26.00de & $24.00 \mathrm{C}$ \\
\hline $\mathrm{B}_{1}$ & $49.00 \mathrm{~cd}$ & $47.67 \mathrm{de}$ & $53.00 \mathrm{~b}$ & $49.89 \mathrm{~B}$ & 26.00de & $28.00 \mathrm{~d}$ & $38.00 \mathrm{~b}$ & $30.67 \mathrm{~B}$ \\
\hline \multirow[t]{2}{*}{$\mathrm{B}_{2}$} & $51.33 \mathrm{bc}$ & $52.00 \mathrm{bc}$ & $62.00 \mathrm{a}$ & $55.11 \mathrm{~A}$ & $35.00 \mathrm{c}$ & $35.00 \mathrm{c}$ & $44.00 \mathrm{a}$ & $38.00 \mathrm{~A}$ \\
\hline & 46.67B & $48.22 \mathrm{~B}$ & $54.67 \mathrm{~A}$ & 7 & $27.67 \mathrm{C}$ & $29.00 \mathrm{~B}$ & $36.00 \mathrm{~A}$ & \\
\hline
\end{tabular}

${ }^{*}$ and ${ }^{* *}$ refer to the specific effect of investigated calcium and boron concentrations, respectively. Capital letters were used for distinguishing between values in specific effect for each investigated factor. Meanwhile, small letters used for interaction effect of their combinations. Means followed by the same letter's are not significantly different at 0.05 level.

\section{Conclusion}

Generally, it could be concluded that, the treatment of $(0.6 \%$ of B x $2.0 \%$ of Ca) as a foliar fertilizers had more pronounced effect on fruit set, yield and fruit quality as well as leaf mineral content of "Kelsey" plum trees.

\section{References}

Association of Official Agricultural Chemists (A.O.A.C) (1985) "Official Methods of Analysis” Benjamin Franklin Station, Washington, D.C., U.S.A., 495-510.

Chapman, H.D. and Pratt, F. (1961) Methods of Analysis for Soils, Plants and Water, Univ. of Calif., 35 (5), 6-7.

Duncan, D.B. (1955) Multiple range and multiple F. Tests. Biometrics, 11, 1-42.

Eissa, F.M. (2003) Effect of some biostimulants on vegetative growth, yield and fruit quality of "Kelsey" plum. Egypt. J. Apple. Sci., 18, 716-735.

Gobara, A.A. (1998) Response of of "Le-Conte" pear trees to foliar application of some nutrients. Egypt J. Hort., 25 (1), 55-70.

Hansch, R. and Mendel, R.R. (2009) Physiological functions of mineral micro-nutrients $(\mathrm{Cu}, \mathrm{Zn}, \mathrm{Mn}, \mathrm{Fe}, \mathrm{Ni}, \mathrm{Mo}, \mathrm{B}$ and $\mathrm{Cl})$. Current Opinion in Plant Biol., 12, 259-266.

Egypt. J. Hort. Vol. 40, No.1 (2013) 
Hisaw, L. (1991) Calcium sprays influence on apple fruit quality and storage shelf life. Compact Fruit Tree, 24, 75-79.

Jackson, M.L. and Ulrich, A. (1959) Analytical methods for use in plant analysis. Coll. of Agric. Exp. State Bull.766, 35 p.

Kabeel, H. (1998) Effect of some growth regulators on fruit set, yield and fruit quality of "Costata" persimmon trees. Minufiya J. Agric. Res., 24 (5), 1727-1739.

Kabeel, H., Eliwa, G.I. and Shaddad, G. (1999) Influence of spraying gibberellic acid, boron and their combinations on fruit set, yield, fruit quality and leaf mineral content of "Le-Conte" pear trees. J. Agric. Sci. Mansoura Univ., 24 (11), 6867-6877.

Kabeel, H., Somia Fawaz, A. and Mehaisen, S.M.A. (2010) Influence of boron foliar sprays on productivity, fruit quality and storability of "Kelsey plums". Egypt. J. Appl. Sci., 25 (10A), 276-691.

Kadir, S.A. (2004) Fruit quality at harvest of "Jonathan" apple treated with foliar applied calcium chloride. Journal of Plant Nutrition, 27 (11), 1999-2006.

Kilany, A.E. and Kilany, O.A. (1991) Effect of potassium and boron nutrients on growth, yield and fruit quality of "Anna" apple trees. Bull. Fac. Agric., Cairo, Univ. 42 (2), 415-428.

Kim, W.C. (1985) Analysis of leaf boron and effects of boron on fruit tree growth. Technical Bulletin, ASPAC-Food and Fertilizer Technology Center, 91,14-28.

Mehaisen, S.M.A and El-Sharkawy, Sh.M.M. (2005) Effect of boron and zinc foliar sprays on productivity, fruit quality and storability of guava trees. Minufiya J. Agric. Res., 30 (4), 1179-1189.

Moon B.W., Lu, W.L., Zheng, H.L. and Choi, J.S. (2002) Effect of three sprays of liquid calcium compounds on the calcium contents, quality and cell wall structure change of "Jingfen" pear fruits. J. Korean Soc. Hort. Sci., 43 (1), 51-53.

Murphy, J. and Riely, J.P. (1962) A modified single method for the determination of phosphorus in natural water. Anal. Chemi. Acta, 27, 31-36.

Picchioni, G.A., Weinbaum, S.A. and Brown, P.H. (1995) Retention and the Kinetics of uptake and export of foliage applied, labeled boron by apple, pear, prune and sweet cherry leaves. $J$. Amer. Soc. Hort. Sci., 120 (1), 28-35.

Pregl, E. (1945) Quantitative Organic Microanalysis, $4^{\text {th }}$ ed., J. \& A Charchill, L.T.D. London. 
Robbertse, P.J. and Coetzev, A. (1991) The influence of solubor leaf spray on fruit production in avocado. South African Avocado Grower's Association 14, 83-84. http:/ www. Avocadosource.com

Robbertse, P.J., Lock, J.J. Stoffberg, E. and Coetzev, L.A. (1990) Effect of boron on directionally of pollen tube growth in Petunia and Agapanthus. S. African J. Bot., 56, 487-492.

Singh, U.P. and Brahmachari, V.S. (1999) Effect of potassium, zinc, boron and molybdenum on the physicochemical composition of guava (Psidium guajava L.) cv. Allahabad Safeda. Orissa J. Hort. 27 (2), 62-65. (Hort. Abst. 71: 3011).

Snedecor, G.W. and Cochran, W.G. (1990) Statistical Methods. $8^{\text {th }}$ ed ., The Iowa State Univ. Press, Iowa, U.S.A., pp.503-507.

Sourour, M.M., Arafat, A.M. and Bahlool, S.E. (1996) Response of "Le-Conte" pear trees to boron sprays. Egypt. Jour. App. Sci., 11 (5), 338-344.

Svagzdys, S. (1995) Use of boron fertilization in apple orchards of Lithuanaia, Acta. Hort., 382, 487-490.

Tabatabaie-S.J. and Malakouti-M.J. (1998) The effect of calcium on fruit firmness and quality in Red Delicious apple. Soil and Water Jour., 12 (1), 43-49.

Vogel, A. (1968) A Text Book of Quantitative Inorganic Analysis. Longmans, New York, p. 1216.

Vojcik, P., Kowalczvk, W. Jakubczvk, H. Lata, B. Sadowski, A. and Whitehead, P. (1998) Effect of boron fertilization on growth, yield, fruit quality and mineral composition of plum leaves. Ecological aspects of nutrition and alternatives for herbicides in horticulture. International seminar, Warszawa, Poland, 18, 96-100.

Westwood, M.N. (1978) Temperate Zone Pomology, W. H. Freeman and Company. San Francisco.

Youn, C.K., Kim, S.K., Lim, S.C., Kim, H.H., Kim, Y.H., Lee, C.H. and Choi, K.S. (2000) Effect of GA paste and calcium chloride on tree growth, fruit quality and storeability of "Niitaka" pears. Journal of the Korean Society for Hort. Sci., 41 (5), 517-522. 


\section{تأثير الرش الورقى بالكالسيوم والبورون على قياسات الإثمار وصفات الجودة والحالية الغذائية لأوراق أثجار البرقوق (كلزى)}

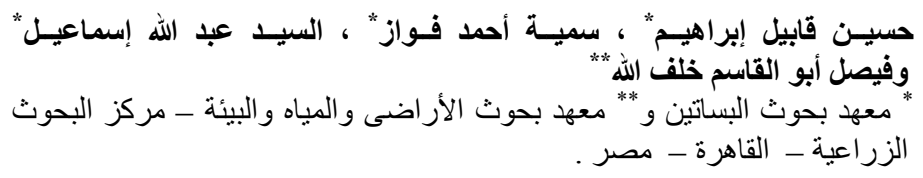

* هذا البحث أجرى بغرض دراسة تأثير الإضافة الورقية (الرش) بكل من الكالسيوم

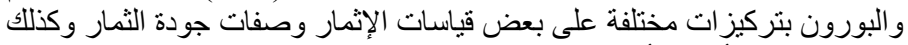

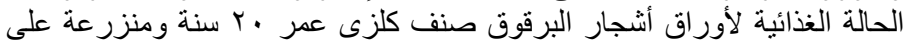

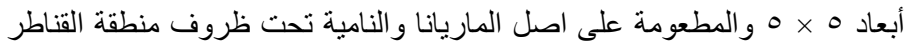

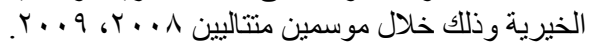

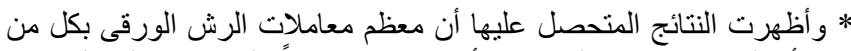

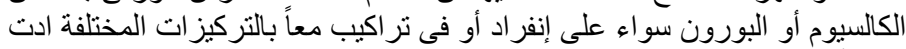

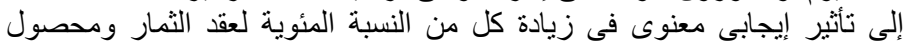

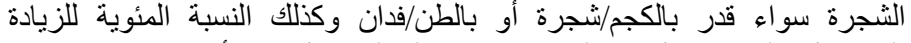

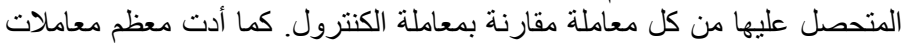
التجربة إلى نقص فى النسبة المئوية لتساقط الثمار فى كلا موسمى الدراسة.

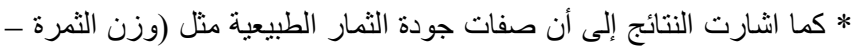

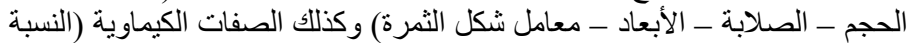

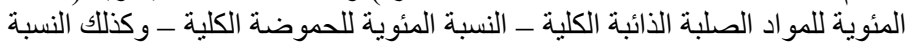

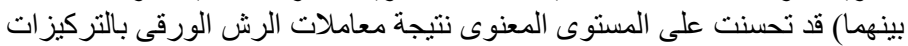

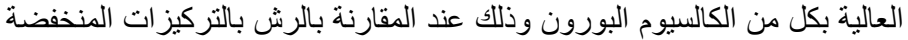

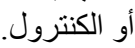

* إضافة إلى ما سبق فإن النتائج أوضحت أن محتوى الأوراق من بعض الثضاء

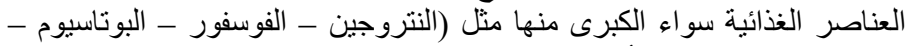

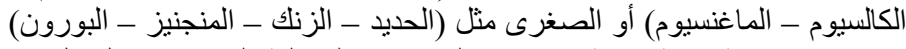

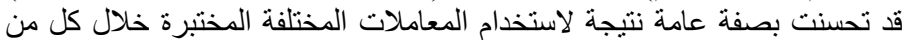

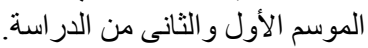

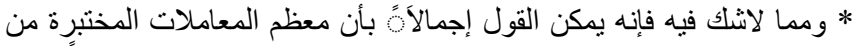

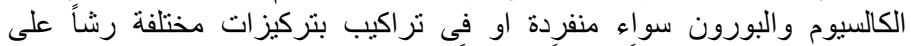

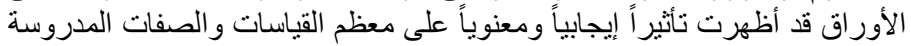

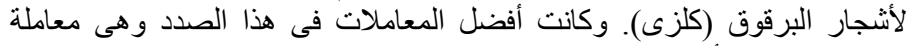

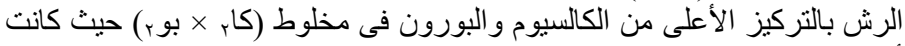

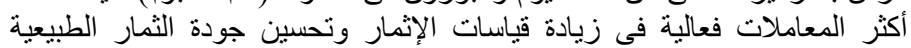

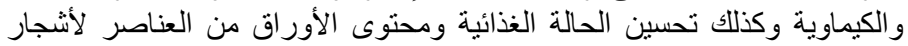

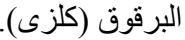

